\title{
製鋼スラグ粒子を高含水比の粘土と 混合したときの粒子の安定性に関する研究
}

\author{
片山 遥平 1 ・土田 孝2 \\ 1 学生会員 広島大学大学院工学研究科（干739-8527 広島県東広島市鏡山 1-4-1） \\ E-mail: m144970@hiroshima-u.ac.jp \\ 2 正会員 広島大学教授 大学院工学研究院（干739-8527 広島県東広島市鏡山 1-4-1） \\ E-mail: ttuchida@hiroshima-u.ac.jp
}

\begin{abstract}
加水調整した粘土スラリーは，固化材を添加して傾斜護岸の裏込めに打設したり，砂質土地盤上に造成 される海面処分場の遮水層として敷設されるなど，港湾・海洋事業における人工地盤材料として様々な用 途に使用されている。用途によっては大きい単位体積重量が求められる場合があり，重量調整材としてレ キや製鋼スラグを混合することが考えられる。レキ粒子が粘土スラリー内で安定する力学条件を調べ材料 分離現象との関係を明らかにすることを目的として，単粒子が粘土スラリー内で安定する力学条件を実験 的に調へ，材料分離現象との関連を検討した。
\end{abstract}

Key Words : marine clay, steel slug, separation characteristics

\section{1. はじめに}

海底面が砂質地盤である地点に管理型処分場を設置 する場合，底面の遮水を行う必要がある．底面遮水の方 法として，海成粘土に間隙調整材（ベントナイト）とゲ ル化剂を配合した土質遮水材料を一定の厚さで敷設する 工法が開発されている1,2,3). 土質遮水材料は，使用する 材料が無機の自然材料であるため経年劣化せず，セメン 卜など固化材を使用しないため変形入追随性を有するこ とから, 長期的に海面処分場の遮水性能を維持すること が可能である. 本工法は平成16年に建設された愛媛県四 国中央市の寒川東部産業廃棄物処分場に適用され ${ }^{4), 5}$,

$45,000 \mathrm{~m}^{2}$ の面積に, 厚さ $2 \mathrm{~m}$, 全体で約 $100,000 \mathrm{~m}^{3}$ のスラ リー状の土質系遮水材料が海水中に打設された.

本工法を施工する上で問題となる点として，底面遮水 材料を打設した層の下に作用する揚圧力がある．海面に 立地した管理型廃棄物処分場では，廃棄物を投入する前 に底面および側面の遮水が行われるが，処分場内の水位 は一般に平均潮位付近よりも低く設定される.このため 処分場の外の水位が処分場内の水位よりも高くなると底 面遮水層の下部に揚圧力が作用する．寒川東部産業廃棄 物処分場の工事においても，底面遮水層を安定させるた めにはカウンターウエイトとなる覆士が施工された．以 上のような揚圧力を考慮すると, 底面遮水に用いる土質 系遮水材料は単位体積重量が大きいことが望ましい.

人工的に混合した地盤材料の単位体積重量を増加さ
せる方法としては，レキあるいは重量の大きい製鋼スラ グ (粒子密度約 $3.44 \mathrm{~g} / \mathrm{cm}^{3}$ ) を重量調整材として混合する 方法が考えられる. レキを混合すると透水係数が変化す る可能性があるが，粘土スラリーに各種の条件で砂を混 合して透水係数を求めた実験より砂分を $50 \%$ 程度混合し ても, 粘土スラリーの透水係数はほとんど変化しないこ とが報告されている11. 海面処分場の遮水層以外でも港 湾・海洋事業において粘土スラリーは様々な用途に使用 される可能性があり，単位体積重量が求められる場合に は重量調整材としてレキや製鋼スラグの混合が考えられ る.しかし，高含水比の粘土にレキや製鋼スラグなどの 粒子を混合した場合，これらの粒子が粘性土内で沈降・ 分離して下層に堆積し，材料としての均一性が失われる ことが懸念される.

本研究ではレキ粒子が粘土スラリー内で安定する力 学条件を調べ材料分離現象との関係を明らかにすること を目的として，単粒子が粘土スラリー内で安定する力学 条件を実験的に調べ,材料分離現象との関連を検討した.

\section{2.＼cjkstart粘土スラリー内での単粒子沈降実験}

\section{（1）沈降実験の方法}

実験には徳山港粘土（液性限界 $110.6 \%$ ，塑性限界 $40.0 \%$ ，土粒子密度 $\left.2.616 \mathrm{~g} / \mathrm{cm}^{3}\right)$ を用いた。用いた模型 固体を写真-1 に示すが，アルミ板，アルミ棒，プラスチ 
ック板を用い,アルミ板で作った箱の内部に鉄粉, 鉛玉, 砂を充填して重量を調整した，供試体が立方体の時と球 体の時では条件が異なるが，今回は模型の作りやすさを 考慮して供試体は立方体を採用した。表-1に，本実験で 用いたレキ模型の寸法と密度を示す. 模型個体の密度と しては製鋼スラグ(密度 $\rho=3.44 \mathrm{~g} / \mathrm{cm}^{3}$ )の密度を基準とし たが，沈降条件を検討する上で参考とするため約 2 倍の 密度の模型も用いた. 粘土スラリーの含水比は， $130 \%$, $140 \%, 145 \%, 150 \%, 155 \%, 160 \%$ の 6 条件とした。

図-1 は沈降実験の方法を示している. まず徳山港粘土 に水を加えて含水比を調整し, 十分に擋汼した後, ベー ンせん断強度を測定した. 次に, 粘土スラリーを直径 110 $\mathrm{mm}$, 高さ $130 \mathrm{~mm}$ のプラスチック容器に入れ, 模型固体 を粘土スラリーの中に模型の高さ分埋め込んだ状態で沈 降を開始した. 模型の沈降量は模型の上に取り付けたプ ラスチック板の沈降量を非接触センサーで測定すること により求め, 測定時間は 1 時間とした.

図-2 は各含水比における試験前と試験後におけるべ ーンせん断強度である. 図のように, 含水比とせん断強 度には一定の関係があるが, 含水比の条件が同じでも試 験ごとにベーンせん断強度の值にはばらつきがあった。 この原因は含水比が同じでも地盤作成時の攪乱の程度や, 試験開始までのシキソトロピーによる強度回復の程度に 差があったためと考えられる. せん断強度の值は含水比 130\%のときに $0.55 \mathrm{kPa} \sim 0.67 \mathrm{kPa}, 160 \%$ のきは $0.20 \mathrm{kPa}$ 〜0.25 kPaであった.

\section{(2) 実験結果}

図-3(a)〜(e)は，5種類の模型を用いた場合のそれぞれ の時間と沈降量の関係である. 図のように 60 分間の沈降 量の最大は $3.42 \mathrm{~mm}$ であり (模型 5), 最小は $0.10 \mathrm{~mm}$ で あった，沈降量に大きな差があるが，時間と沈降の関係 はいずれもよく類似しており, 沈降は最初の 10 分間に急 速に進行し，10 分経過後はほぼ安定した速度となってい る. 今回は沈降量の計測を 60 分間行ったが, ほとんどの 場合 60 分が経過しても沈降は継続している. しかしな がら沈降速度は含水比および模型の条件によって大きく 異なっている.

図をみると，模型 $3 ， 4 ， 5$ ではいずれも含水比が大き くせん断強度が小さいほど沈降量は大きく, 含水比が小 さいせん断強度が大きいほど沈降量は小さくなっている. 模型 1 と模型 2 では含水比と沈降量の関係が上記の逆に なっている場合があるが，全体としてみると含水比すな わち粘土のせん断強度と沈降量にはほぼ一定の関係があ ることがうかがえる.

以上の結果より, 粘土スラリー中の模型の沈降を支持 力問題として検討することとする.

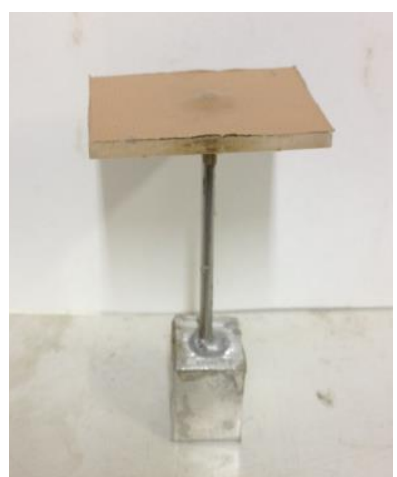

写真-1 模型個体

表-1＼cjkstart試験に用いた模型の寸法と密度

\begin{tabular}{|c|c|c|c|c|}
\hline $\begin{array}{c}\text { 模型 } \\
\text { 番号 }\end{array}$ & $\begin{array}{c}\text { 幅 } \\
(\mathrm{cm})\end{array}$ & $\begin{array}{c}\text { 奥行き } \\
(\mathrm{cm})\end{array}$ & $\begin{array}{c}\text { 高さ } \\
(\mathrm{cm})\end{array}$ & $\begin{array}{c}\text { 密度 } \\
\left(\mathrm{g} / \mathrm{cm}^{3}\right)\end{array}$ \\
\hline 1 & 1.23 & 1.21 & 1.35 & 3.51 \\
\hline 2 & 2.09 & 2.13 & 2.02 & 3.21 \\
\hline 3 & 2.06 & 2.10 & 2.09 & 6.40 \\
\hline 4 & 3.21 & 3.19 & 3.08 & 3.37 \\
\hline 5 & 3.24 & 3.14 & 3.08 & 6.46 \\
\hline
\end{tabular}

曰匹非接触せンサー

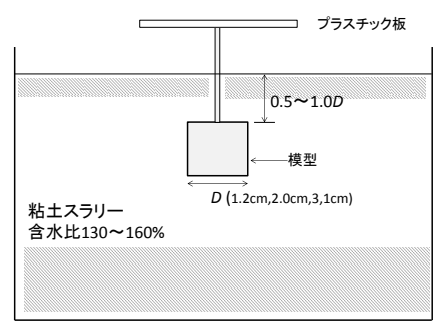

図-1 単粒子沈降実験の方法

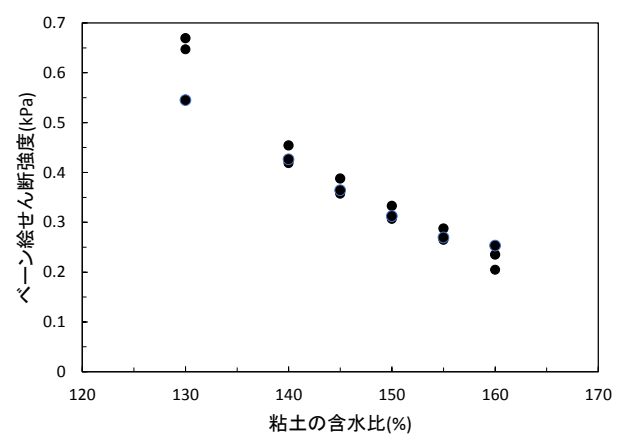

図-2＼cjkstart粘土スラリーのベーンせん断強度

\section{3. 支持力理論を用いた安全率と沈降量の関係}

図-4に支持力問題としての考え方を示した. 模型の底 面において模型の重量による分布荷重を考えると，分布 荷重の大きさは模型重量から模型の体積分の粘土スラリ 一の重さを引いた重量を模型底面積で割った值となる. この分布荷重に対して, 粘土スラリーの粘着力 $c$ による 模型底面における地盤支持力を考え， $\varphi=0$ のときの帯基 礎の支持力係数 $N_{\mathrm{c}}=5.14$, 正方形基礎に関寸る形状係数 1.3 を用いると支持力は $(5.14 \times 1.3) c$ となる ${ }^{6}$ (ここでは模 


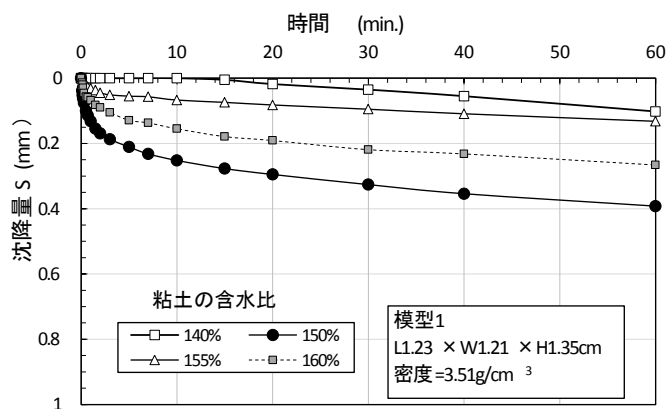

(a) 模型 $1 \quad\left(1.23 \times 1.21 \times 1.35 \mathrm{~cm}, 3.51 \mathrm{~g} / \mathrm{cm}^{3}\right)$

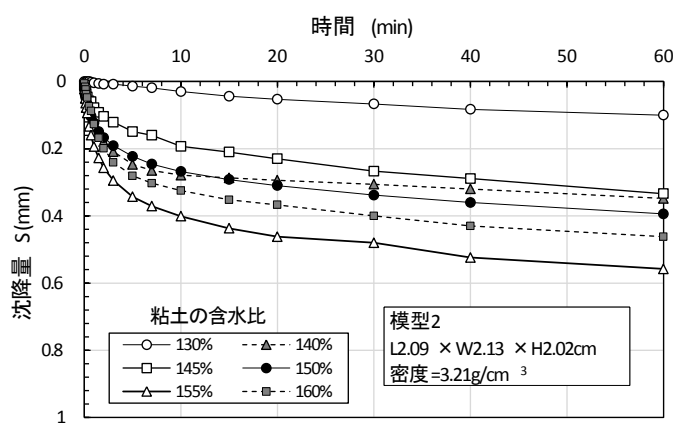

(b) 模型 $2\left(2.09 \times 2.13 \times 2.02 \mathrm{~cm} .3 .21 \mathrm{~g} / \mathrm{cm}^{3}\right)$

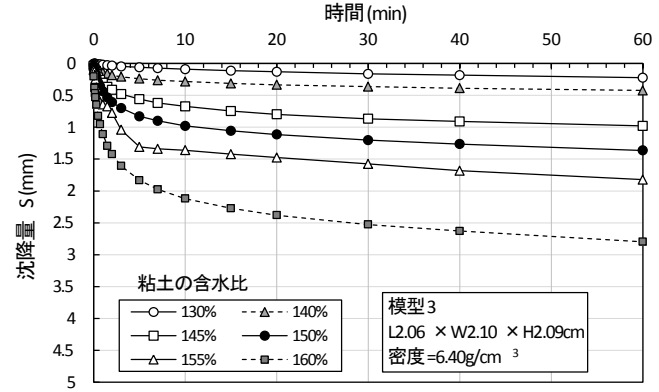

(c) 模型 $3\left(2.06 \times 2.10 \times 2.09 \mathrm{~cm}, 6.40 \mathrm{~g} / \mathrm{cm}^{3}\right)$

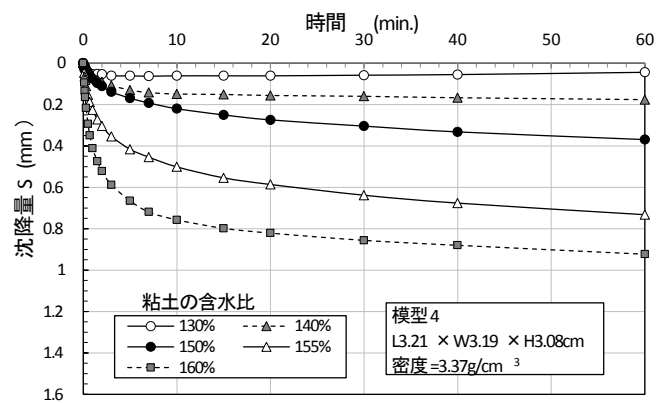

(d) 模型 $4\left(3.21 \times 3.19 \times 3.08 \mathrm{~cm}, 3.37 \mathrm{~g} / \mathrm{cm}^{3}\right)$

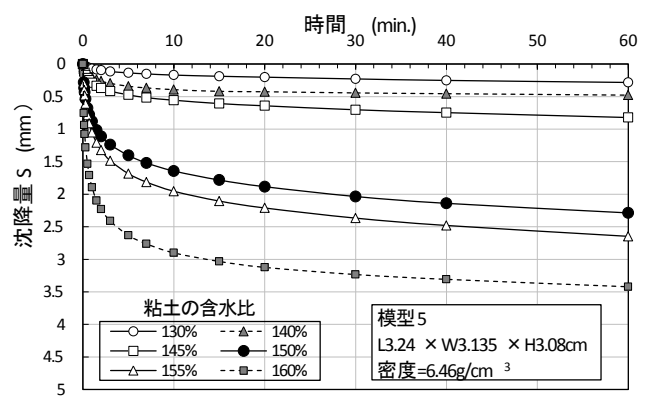

(e) 模型 $5\left(3.24 \times 3.19 \times 3.08 \mathrm{~cm}, 6.46 \mathrm{~g} / \mathrm{cm}^{3}\right)$

図-3 時間と沈降量の関係
型側面に働く粘着力は無視する). 以上より，支持力に 関する安全率 $F$ は次式で計算することができる.

$$
F=\frac{c_{u(\text { vane })} \times 5.14 \times 1.30}{\frac{W-W_{\text {clay }}}{A}}
$$

ここに， $c_{\mathrm{u}(\mathrm{vane})}$ : ベーンせん断強度， $W$ : 模型質量, $W_{\text {clay }}$ : 模型個体の体積分のスラリーの重量, $A$ : 模型個 体底面の断面積である.

図-5 は底面とともに側面に働く粘着力を考慮した ときの支持力の考え方である．側面に付着した粘土の 粘着力により上向きの力が働いているとすると，支持 力に関する安全率 $\mathrm{F}$ は次式のようになる.

$$
F=\frac{c_{u(\text { vane })} \times(5.14 \times 1.30+B / A)}{\frac{W-W_{\text {clay }}}{A}}
$$

ここに $B$ は 4 つの側面の面積の合計であり，模型が 立方体の場合 $B / A=4$ となる. 式(1)による安全率を計算 し，断面積がほぼ $2.0 \mathrm{~cm} \times 2.0 \mathrm{~cm}$ である模型 2 および 模型 3 について経過時間 5 分および 60 分のときの安全 率と沈降量の関係を図-6に示した，図をみると，経過 時間5分と60分のいずれにおいても安全率がそれぞれ 1.7 と 2.0 よりも小さくなったときに沈降量が急激に増 加する傾向が見られる. 寸なわち，粘土スラリ一中の 個体の沈降を支持力問題として考えた場合，式(1)によ る安全率 1.7〜2.0 が沈降に関する限界值を表している 可能性がある.

同様の整理を，各辺の寸法が約 $1.2 \mathrm{~cm}$ の模型 1 につ いて行ったのが図-7である.今回用いた含水比と立方 体の密度ではいずれも安全率が 3.5 以上になっている が, 経過時間 5 分および 60 分における沈降量は図中に 示す模型寸法約 $2.0 \mathrm{~cm}$ のとき関係を示す線の值とほ

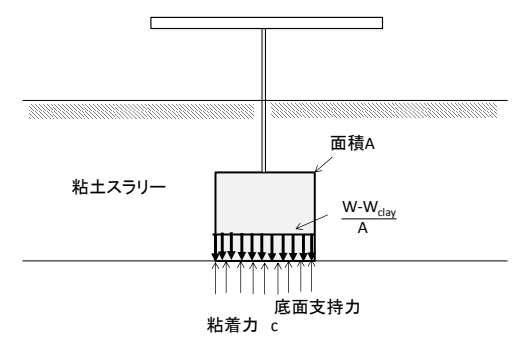

図-4 支持力の考え方（側面抵抗を無視）

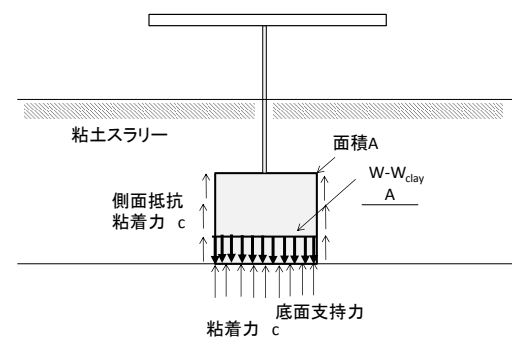

図-5 支持力の考え方（側面抵抗を考慮） 


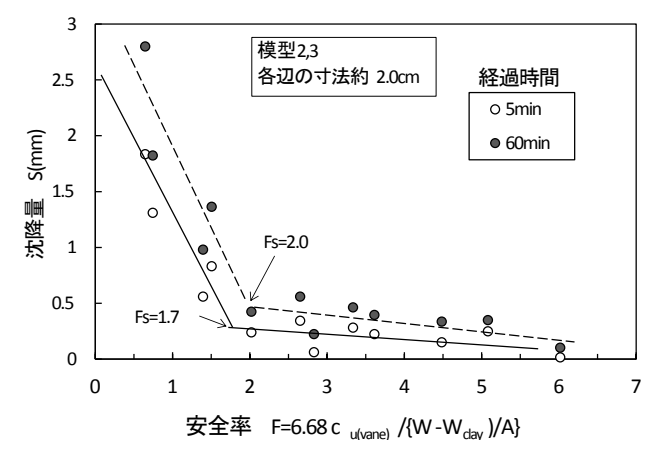

図-6 式(1)の安全率と沈降量の関係（模型 2 と 3)

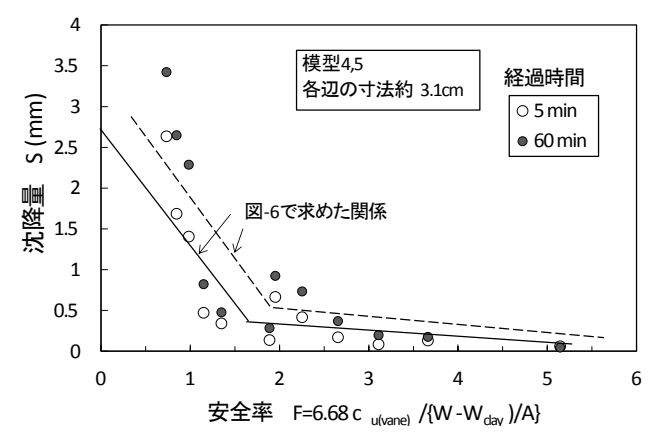

図-8 式(1)の安全率と沈降量の関係（模型 4 と 5)

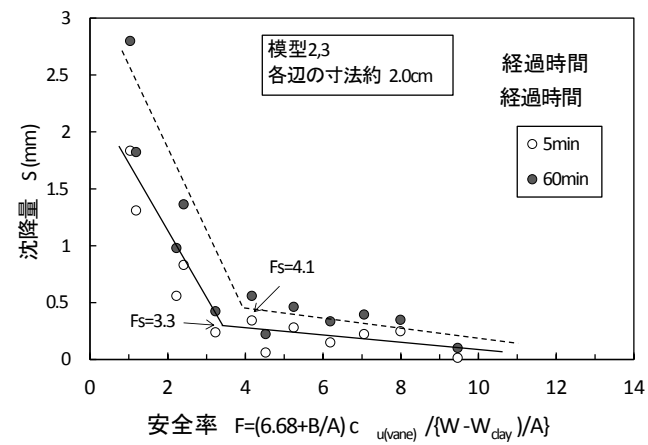

図-10 式(2)の安全率と沈降量の関係（模型 2 と 3)

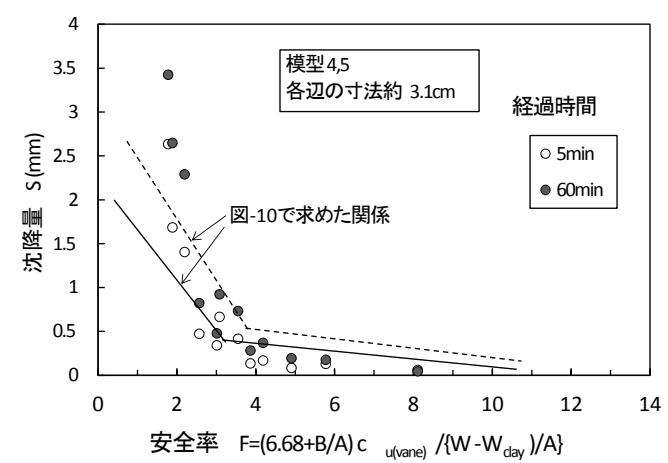

図-12 式(2)の安全率と沈降量の関係（模型 4 と 5)

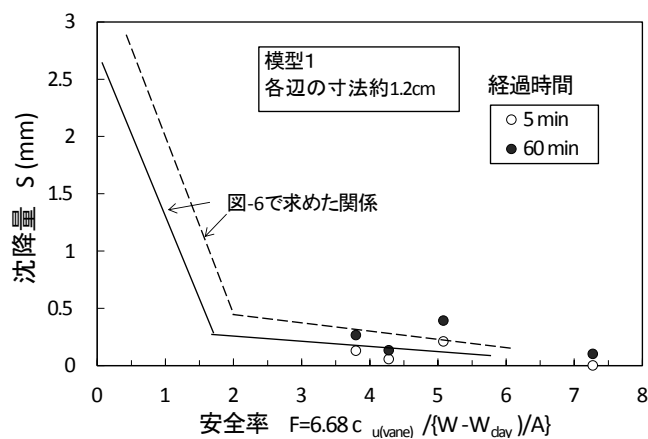

図-7 式(1)の安全率と沈降量の関係（模型 1)

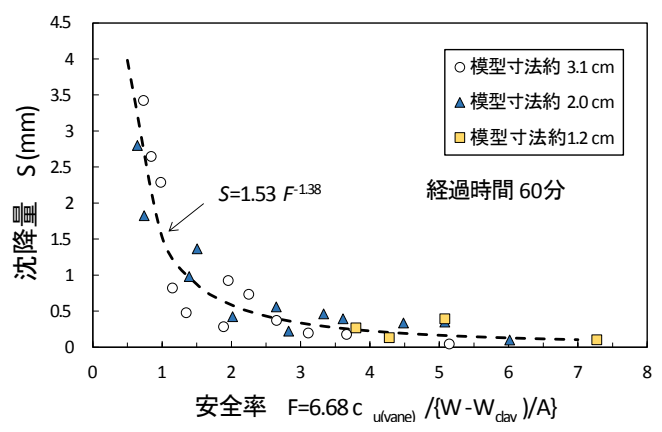

図-9 式(1)の安全率と沈降量の関係（寸法別）

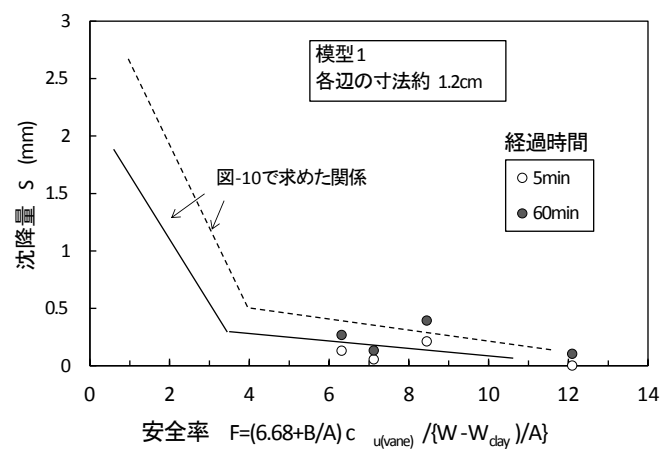

図-11 式(2)の安全率と沈降量の関係（模型 1)

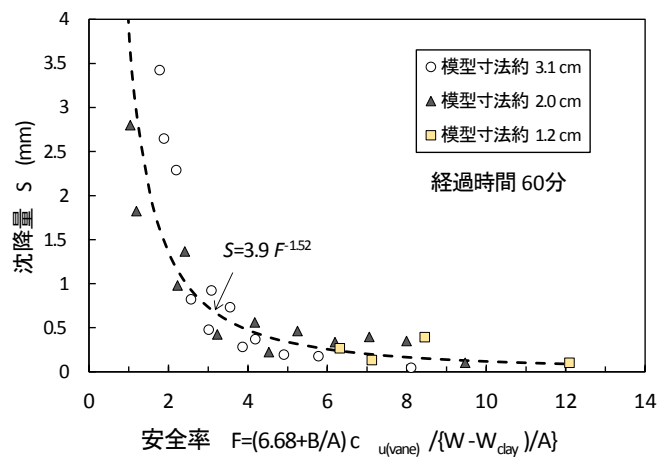

図-13 式(2)の安全率と沈降量の関係（寸法別）

沈降量が急増するのは安全率が 2.5 以下であるといえる.

次に, 模型の側面に働く粘着力を考慮して求めた式(2) による安全率と沈降量の関係を検討寸る．図-10には, 断面積がほぼ $2.0 \mathrm{~cm} \times 2.0 \mathrm{~cm}$ である模型 2 および模型 3 について経過時間 5 分および 60 分のときの式(2)による 安全率と沈降量の関係である.

図-6 と同様に安全率と沈降量には良好な関係がみら 
れるが, 沈降量は経過時間 5 分および 60 分で安全率がそ れぞれ3.3 と 4.1 よりも小さくなったときに急激に増加し ている. したがって，粘土スラリー中の個体の沈降を図 -5のような支持力問題として考えた場合, 式(2)による安 全率では 3.3〜 4.1 が沈降に関する限界值になっている. 各辺の寸法が約 $1.2 \mathrm{~cm}$ の模型 1 および寸法が約 $3.1 \mathrm{~cm}$ の 模型 4，5について同様の整理を行い，図-11 と図-12に 示した. いずれも図中には寸法約 $2.0 \mathrm{~cm}$ のときの安全率 と沈降量の関係を表す線を示しているが，模型の寸法が 異なっても, 安全率 3.5 4.0 以下になると沈降量が急増 するなど，両者の関係はほぼ一致しているといえる.

図-13 は今回用いた 3 種類の模型について経過時間 60 分の沈降量と式(2)による安全率の関係である. 図のよう に, 安全率と沈降量は良好な関連がみられ，式(2)による 安全率を用いると沈降量が急増するのは安全率が 4.5 以 下である.

ここで, 式(1)および式(2)で沈降量が急増するときの安 全率が 1 よりもかなり大きい理由について考察する. 本 解析に用いた強度はベーンせん断強度であり, ベーンを 回転したときのトルクの最大值から求めている．したが って，ベーンせん断強度は粘土が大きく変形したときに 発現する強度であり，模型と接している粘土層の変形を 考慮すると, 図-4, 図-5の支持力問題として考えたとき に発現している粘着力がベーンせん断強度よりも小さい 可能性が考えられる.

安部らは，波浪作用下の底泥の安定を波浪によって発 生する円弧すべり解析によって評価できることを報告し ているが 7)，この場合の粘土層のせん断強度は，ベーン せん断強度の $1 / 6$ 程度であるとしている. 図-14 は, 粘土 スラリーのベーンせん断強度 $c_{\mathrm{u}(\mathrm{vane})}$ と回転粘度計から求 めた降伏值 $\tau_{\mathrm{y}}$ の関係である．図のように，両者の間には 次式のような関係がある。

$$
\tau_{\mathrm{y}}=0.181 c_{\mathrm{u}(\mathrm{vane})}
$$

式(2)より安部らは降伏值をせん断強度として円弧す心゙ り解析を行うことで底泥の安定を評価できるとした．そ こで式(2)のベーンせん断強度を降伏值を置き換えると， 安全率は以下のようになる.

$$
F=\frac{\tau_{y} \times(5.14 \times 1.30+B / A)}{\frac{W-W_{\text {clay }}}{A}}
$$

式(3)より求めた $\tau_{\mathrm{y}}$ から式(4)の安全率を計算し沈降量と の関係を求めると, 図-15のようになった. 図のように, せん断強度として回転粘度計から求めた降伏值を用いた 安全率を用いると, 安全率が 0.7 以下で沈降量が急増し ている. 以上の結果より, 降伏值を強度として求めた安 全率が粒子の沈降をよく説明していると考えられる.

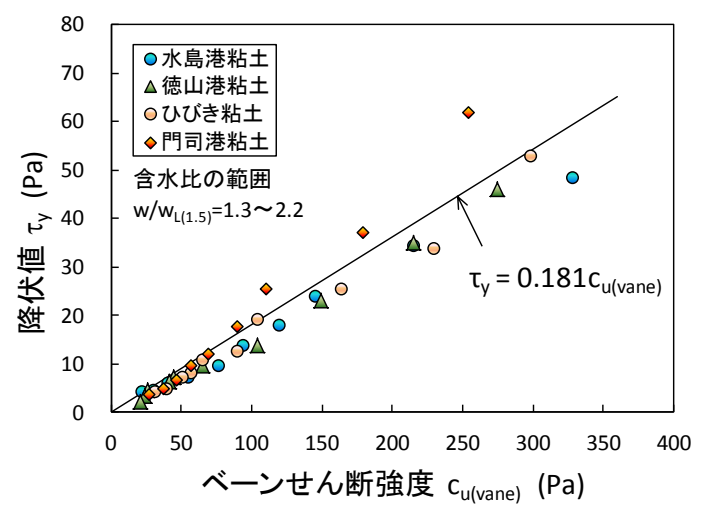

図-14 ベーンせん断強度 $c_{\mathrm{u}(\mathrm{vane})}$ と降伏值 $\tau_{\mathrm{y}}$ の関係

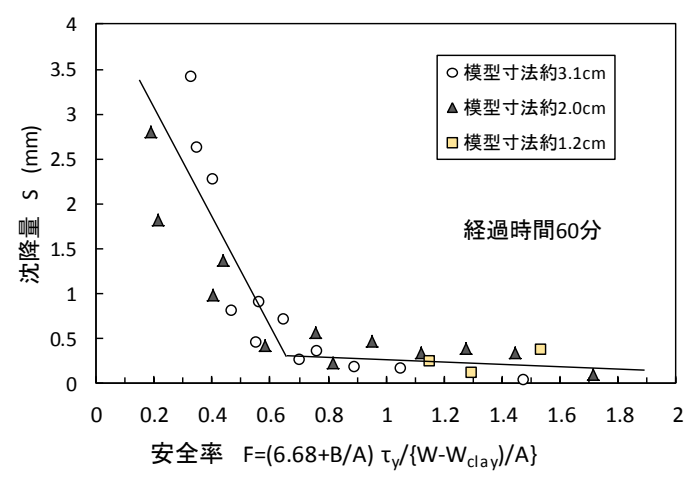

図-15降伏值を用いた安全率と沈降量の関係

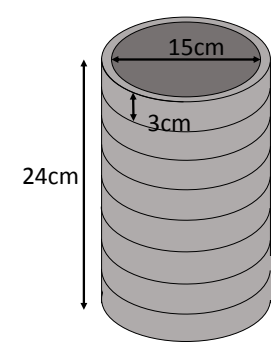

図-16 分離試験に用いた容器

表-2 試験条件と安全率

\begin{tabular}{|c|c|c|c|c|}
\hline $\begin{array}{c}\text { 製鋼スラグ } \\
\text { の直径(cm) }\end{array}$ & \multicolumn{4}{|c|}{ 含水比(\%)と安全率（括弧内） } \\
\hline 1.0 & $130(22.6)$ & $140(15.8)$ & $150(11.6)$ & $160(8.7)$ \\
\hline 2.0 & $130(3.9)$ & $140(2.7)$ & $150(2.0)$ & $160(1.5)$ \\
\hline
\end{tabular}

\section{4. 製鋼スラグと粘土スラリーを混合したとき 分離特性との関連}

製鋼スラグと粘土スラリーを混合したときの分離現 象と沈降試験結果の関連を調べるため, 含水比 130〜 160\%の粘土に重さ3.0〜 4.0 g, 25.0〜 30.0 g の製鋼スラグ 粒子を混合して図-16 に示す容器に充填し, 60 分経過後 に厚さ $3 \mathrm{~cm}$ ごとの密度を測定した. 製鋼スラグの混合率 は海成粘土の乾燥体積に対して $25 \%$ とした. 表-2 に試験 条件と式(1)で求めた単粒子の安全率を示した.

図-17, 18 は混合 60 分後の深さごとの密度分布である. 
図-17のように, スラグ直径が $1 \mathrm{~cm}$ の場合は式(1)の安全 率が 8.7〜22.6 であるが, 深さ $5 \mathrm{~cm}$ 以深の密度は均一と なっている（細かくみると深さ方向に密度の変動が大き いが，これはスラグの粒径に対して密度を測定した粘土 層の厚さ $3 \mathrm{~cm}$ が小さいために生じた誤差と考える).こ のように密度がほぼ均一になっているのは，個々のスラ グ粒子が周囲のスラリーの強度によって拘束され，沈降 せずに安定しているためと考えられる. 一方, 図-18の スラグ直径 $2 \mathrm{~cm}$ の場合は安全率が 1.5〜3.7 であり, 深さ とともに密度が増加する傾向がみられた．これは，スラ リーの強度がスラグ粒子をその位置に固定するためには 不十分であったことを示すと考えられる。

\section{5.まとめ}

レキ粒子が粘土スラリー内で安定する力学条件を調 べ材料分離現象との関係を検討した. その結果，粒子の 沈降を支持力問題を考えて求めた安全率と 60 分後沈降 量には一定の関係がみられ，沈下が急増するのは側面抵 抗を考慮しない式では安全率 2.5 以下，側面抵抗を考慮 した式では安全率 3.5〜4.0 以下であった. さらに製鋼ス ラグ粒子と粘土スラリーを混合し 60 分後の密度分布を 調べた結果, 式(1)の安全率が 8.7 以上の条件では密度が 均一であるが, 安全率が 3 以下の条件では深さ方向に密 度が増加する傾向がみられた。 以上の結果より, 本研究 が提案する安全率により，レキ粒子を粘土スラリーに混 合した時の分離の有無をおおよそ評価できる可能性があ ると考えられる. なお, 本研究の実験では混合後 60 分で 分離を調べているが, 単粒子の沈降は 60 分では完全に停 止していないので，今後計測方法を工夫し長時間経過後 の分離の有無について調べる必要があると考える.

\section{参考文献}

1）渡部要一, 土田孝, 斉藤邦夫, 山田耕一, 上野一彦: 粘土系 遮水材料における微視構造と透水係数の関係, 第 47 回地盤工 学シンポジウム, pp.381-388, 2002.

2)山田耕一, 鵜飼亮行, 伊野同, 土田孝, 渡部要一: 変形追随

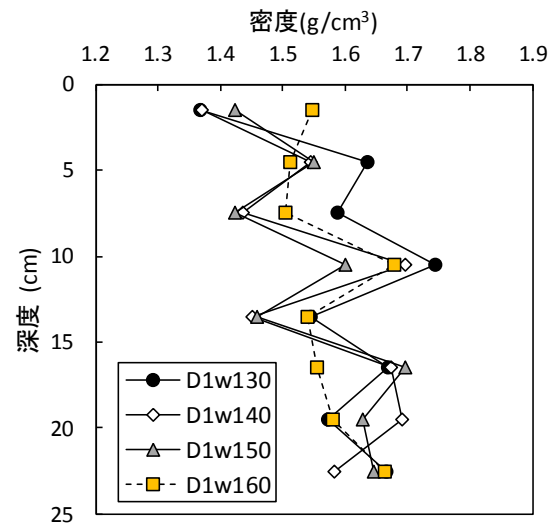

図-17 混合 60 分後の密度分布 $($ スラグ直径約 $1 \mathrm{~cm})$

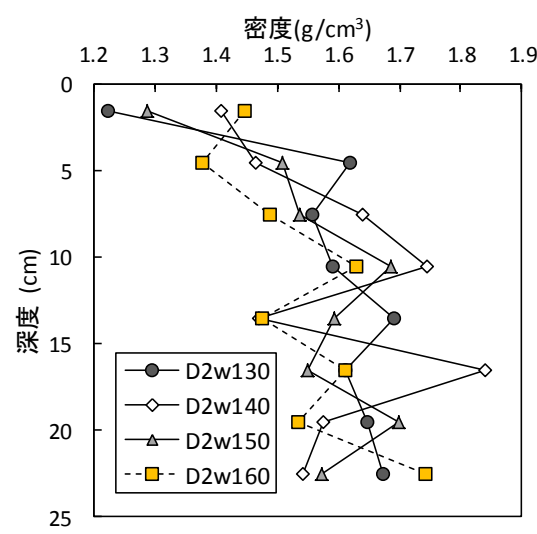

図-18 混合 60 分後の密度分布 $($ スラグ直径約 $2 \mathrm{~cm}$ )

性材料を用いた遮管理型廃棄物海面処分場の遮水工法に関す る実海域実証実験, 海洋開発論文集, 第 19 巻, pp.177-182, 2003.

3) 上野一彦, 山田耕一, 渡部要一 : 管理型海面処分場に用いる 浚渫粘土を主材料とした土質遮水材料の提案，土木学会論文 集 G, Vol.64, No.2, pp.177-186， 2008.

4) 日経 BP : 日経コンストラクション, No.411, pp.30-34, 2006. 5) 川崎隆広, 山田耕一，上野一彦: 海面処分場における土質遮 水材料の施工事例，地盤と建設，Vol.27, No. 1 , 地盤と建設， pp.187-194, 2009.

6) 山口柏樹:土質力学 (全改訂), 技報堂出版, pp.257-272, 1984 .

7) 安部太紀，土田孝，熊谷隆宏 : 波浪作用下における軟弱地盤 の安定性について，土木学会論文集 B2（海岸工学），Vol. 68， p.I_711-I_715, 2012

\section{STABILITY OF SLUG MIXED WITH CALY SLURRY OF HIGH WATER CONTENT}

\section{Yohei KATAYAMA and Takashi TSUCHIDA}

Clay slurry has been used for various purpose in construction works of port and harbour, such as backfilling of revetments or cut-off layer covering sand seabed for off-shore waste disposal sites. For these uses, the large unit weight of clay slurry is desirable. The mixing the slurry with gravel or steel slug is a probable way for increase the unit weight of clay slurry. In this study, the time-settlement property of single solid in clay slurry was investigated by the laboratory test. The stability condition of single solid is given as a safety factor of bearing capacity of clay layer. The proposed safet factor was related to the results of experiment on serigration of clay-slug mixtures. 